\title{
Correction to: Capitalism, Political Participation and the Student as a Revolutionary Figure
}

\author{
Gritt Bykærholm Nielsen (D)
}

\section{Correction to:}

\section{Chapter 10 in: S. Wright et al.,}

Enacting the University: Danish University

Reform in an Ethnographic Perspective, Higher Education Dynamics 53, https://doi.org/10.1007/978-94-024-1921-4_10

The original version of the book was inadvertently published without updating the correct figure caption for Figure 10.3. The caption and the list of figures on page XVI has now been corrected and approved by the author. 